\title{
Logistics Flexibility and Customer Satisfaction in Spain's Furniture Industry
}

\author{
Gonzalo Maldonado-Guzman ${ }^{1}$, Sandra Yesenia Pinzón-Castro ${ }^{1}$, \& Heira Georgina Valdez-Bocanegra ${ }^{1}$ \\ ${ }^{1}$ Centro de Ciencias Económicas y Administrativas, Universidad Autonoma de Aguascalientes, Mexico. \\ Correspondence: Gonzalo Maldonado-Guzman, Centro de Ciencias Económicas y Administrativas, Universidad \\ Autonoma de Aguascalientes, Avenida Universidad No. 940, Ciudad Universitaria, C.P. 20131, Aguascalientes, \\ Mexico.
}

Received: May 31, 2017

doi:10.5539/ibr.v10n8p161
Accepted: July 12, $2017 \quad$ Online Published: July 14, 2017

URL: https://doi.org/10.5539/ibr.v10n8p161

\begin{abstract}
The use of flexibility has been analyzed and discussed in the literature as a strategy that produces many competitive advantages and as an essential resource in enterprises for some decades. However, logistics flexibility is a rather recent construct and a variable that has also been considered as a business strategy that produces not only higher competitive advantages but also a higher level of customer satisfaction. Although logistics flexibility has several benefits in enterprises, there is still in the literature a high percentage of ignorance from a considerable amount of organizations about the effects of logistics flexibility in customer satisfaction. For this reason, the main objective of this empirical research is the analysis of the effects of logistics flexibility on the logistics related to customer satisfaction by using a sample of 322 enterprises in furniture industry in Spain. The results obtained provide empirical evidence of the positive and significant effects that logistics flexibility has on the logistics related to customer satisfaction.
\end{abstract}

Keywords: flexibility, logistics flexibility, customer satisfaction

\section{Introduction}

The use of logistics activities in most companies has increased surprisingly in the last two decades (Knemeyes \& Murphy, 2004; Ashenbaum et al., 2005; Langley et al., 2009). More specifically, the industry of logistics services has developed significantly in this century in almost all countries of the world (Wallenburg, 2009). As a result, in an environment characterized by the globalization of markets, a high level of competitiveness in enterprises and business uncertainty, it is essential that firms have logistics systems or suppliers of efficient and effective logistics services as this will enable organizations to obtain higher and better competitive advantages than their main competitors (Lieb \& Butner, 2007).

In this regard, Lieb and Butner (2007) carried out a survey in industrial enterprises of the United States. They found out that the business that had more flexible logistics systems were more competitive than their main rivals. Similarly, Bowersox et al. (1989) had already provided enough empirical evidence that the firms that use logistics practices regularly obtained higher competitive advantages when they applied a higher level of flexibility in order to satisfy rapidly and efficiently the needs and requirements of their customers and consumers. For this reason, flexibility has been considered in literature as an essential variable not only to obtain/improve their competitive advantage significantly but also as a business strategy (Fawcett et al., 1996).

Thus, the concept of flexibility was used as a business strategy at the beginning of the 1970s as an essential variable in the raise of the level of competitiveness at a global level in the $80 \mathrm{~s}$ and $90 \mathrm{~s}$. As a result, flexibility has received a lot of attention in the context of logistics activities and even more when the role of flexibility in organizations is analyzed in its relationship with the satisfaction of the needs and interests of customers (Noordewier et al., 1990; Cannon \& Homburg, 2001; Homburg et al., 2003). Consequently, flexibility is considered in the literature as an essential requirement for the very survival of enterprises (Verdú-Jover et al., 2006), and it also represents an essential element for the management of business uncertainty (Sánchez, 1995; Verdú-Jover et al., 2006).

Additionally, when the flexibility is combined with the logistics activities, it allows firms to improve significantly the satisfaction of customers by reducing distribution costs in an important way (Naim et al., 2006). 
Likewise, it is important to guide future empirical studies so they analyze logistics flexibility and its relation to customer satisfaction, in order to obtain more evidence of the existing relation between both constructs (Hill, 1985; Slack, 1990; Naim et al., 2006). Therefore, the main contribution of this paper is the analysis of both constructs in Spanish enterprises in the furniture industry with a sample of 322 firms by following the recommendations of Stank et al. (2003), Knemeyer and Murphy (2004), Knemeyer and Murphy (2005a, b), Deepen et al. (2008), Wallenburg (2009), Grawe et al. (2011) as well as Hartmann and De Grahl (2011).

\section{Method}

The concept of flexibility has received a lot of attention in the literature of business and management sciences, it has usually been analyzed from different points of view such as the case of production flexibility (Shang \& Marlow, 2005), but it has not received the same level of attention in the context of management in the supply chain and logistics (Hartmann \& De Grahl, 2011), even when at the beginning of the 90s an important number of firms acknowledged the necessity to consider their suppliers, the suppliers of the suppliers and their customers. This trend, called supply chain and logistics management (Lummus et al., 2003), changed the perspective of enterprises from focusing in the internal management of business processes to focusing in managing the processes among firms.

With this in mind, flexibility has commonly been defined as the capacity that enterprises have to adapt to new and different situations, or to the changes and requirements of the market (Fawcett et al., 1996: 172). Correspondingly, there are other definitions of flexibility which refer in general terms to the ability of firms to adapt to the necessities and dynamics of the business environment (Bower \& Hout, 1988), or to their ability to rearrange their resources and activities quickly as an answer to the demand of the environment (Wright \& Snell, 1998). Henceforth, flexibility can be considered as a proactive attribute that allows enterprises, to adjust and react to the changes demanded by the market in order to improve significantly their processes, functions and organizational skills (Naim et al., 2006).

Similarly, flexibility has been related frequently to high levels of business return (Upton, 1995a, b, c; Johnson et al., 2003; Stevenson \& Spring, 2007). For this reason, the three main business strategies that have appeared at the beginning of the new century in the literature of business and management sciences are costs reduction, the improvement of quality of products and/or services and the improvement of responsibility (flexibility in the distribution and delivery time of products) (Lummus et al., 2003). Hence, flexibility is generally considered in the literature as a logistics capacity and as the degree to which companies, can adjust quickly to the supply chain in order to attain a higher level of business return (Lummus et al., 2003).

Therefore, in the supply chain where raw materials and products move in a sequential way from one commercial associate to another, an important number of firms that participate in the market have understood that they have to be more responsible to their customers' demands so they feel more satisfied. That is why all the associates that participate in the supply chain must have more flexible logistics systems, in order to respond more efficiently to the changes demanded by the business environment (Aprile et al., 2005). Under those circumstances, enterprises must be more flexible with their transactions, especially in the area of logistics, in order to implement procedures that allow a high level of variation in the sequence and delivery of orders requested by customers (Carlsson, 1989), as well as to improve significantly the ability of enterprises to act efficiently and effectively to the changes and dynamics of the market (Sánchez, 1995; Ling-Yee \& Ogunmokun, 2001).

On the other hand, Fawcett et al. (1996) analyzed in detail the essential elements of logistics flexibility in an international level and concluded that, both the usefulness of information and the level of expansion of strategic planning are the two intrinsically elements that enterprises must have that participate in an international market. By using the example of Wal-Mart, Stank et al. (1992) considered that logistics flexibility is an essential capacity of firms to attain a higher level of competitiveness. Likewise, Stank et al. (1992) concluded that the intersection of terminals, communication systems via satellite and the property of the transportation fleet are the essential elements that logistics activities must have in order to be flexible.

Accordingly, Daugherty and Pittman (1995) considered that the responsibility of allocation is a fundamental factor of logistics flexibility. Other researchers and scholars have considered the choice of transportation and its associated costs as inherent elements of logistics flexibility. Baumol and Vinod (1970) were the first researchers that considered the choice of transportation and inventory from a point of view of a costs model as central elements in logistics flexibility. Furthermore, Buffa and Reynolds (1977), Jayaraman (1998) as well as Vannieuwenhuyse et al. (2003), analyzed a transportation model that includes and important number of variables related to transportation as essential elements of logistics flexibility.

Additionally, Kogut (1985) came to the conclusion that logistics flexibility plays a fundamental role in the 
coordination and success of the global strategies of enterprises, since most of the organizations participate in international markets have effective logistics systems and the flexibility of production, is necessary to extend the global reach of their products. Consequently, logistics flexibility can be considered as one of the best options to get a significant increase in the level of firm's competitiveness, because once they have succeeded in raising their level then the next step will be the production flexibility so companies can satisfy the needs and interests of their customers (Fawcett et al., 1996).

This is the main point; organizations are nowadays a clear example of the changes in the preferences and interests of customers. They need a better specification in the requirements of products from their customers; they need a higher expectation in the provision of services and a constant pressure to reduce the costs of products and services (Jenkins \& Wright, 1998). Thus, logistics flexibility is vital to react to the demands of clients by changing the structure and levels of systems, because the changes in the structure includes the processes, material resources and relations whereas the changes in systems involve the use of information decision making (Jenkins \& Wright, 1998; Closs et al., 2005).

To sum up, and based on the information presented above, it is possible to state that the adoption and implementation of logistics flexibility is essential for three basic reasons. Firstly, the recent trends of the market such as the customization of products from clients require logistics flexibility systems, that satisfy the demands and needs of clients without adding up significant costs (Gilmore \& Pine, 1997; Pine, 1997; Lummus et al., 2003; Esper et al., 2007), because most enterprises are nowadays collecting information about the preferences and needs of customers, and consumers so they create products for specific clients and consumers.

Secondly, there are some industrial sectors such as high technology that require flexible logistics both internal and external (Lummus et al., 2003), since this kind of enterprises usually need to increase or decrease their level of production (20\% or more), in a relatively short time for a new level of production planning. That is why logistics flexibility facilitates this new level of production. Thirdly, in some of the categories of innovative products such as clothing and electronic devices, the uncertainty of the demand is a real fact that firms face and that is because the implementation of flexible and responsible logistics is one of the most efficient methods to avoid as much as possible the uncertainty in business (Fisher, 1997).

Additionally, any change in the business environment that could make enterprises to look for the basic requirements, by themselves to introduce into the market new products quickly that are demanded by clients and respond efficiently and effectively to the needs of clients anywhere in the world, logistics flexibility will play an essential role in the achievement of these goals as it will depend on the fulfillment of orders as fast as possible and at the lowest possible cost (Lummus et al., 2003; Aprile et al., 2005; Esper et al., 2007). Chase et al. (2000: $89)$ summarized accurately the changes in the business environment in a clear way:

"The recent trends, such as outsourcing and customization of products, have forced enterprises to look for new ways of flexibility to meet clients'demand. Focusing on the optimization of the main activities of organizations is the most efficient and effective way to respond to the changes in the expectations of clients".

Within this context, Ansoff and Brandenburg (1971) came to the conclusion that the fast changes in the preferences and needs of clients, and a higher use of technology in production processes of products were forcing enterprises to be more sensitive and flexible. Therefore, the increase of diversity and uncertainty in the environment of business has led an important number of firms to quickly and soundly to this type of changes demanded by the market along with logistics flexibility, as a business strategy to achieve a higher satisfaction of their clients and customers (Martinez \& Perez, 2005; Oke, 2005; Kayis \& Kara, 2005; Chang et al., 2005; Julie, 2005; Verdú-Jover et al., 2006; Gebauer \& Schober, 2006; Tang \& Sia, 2006).

As a result, several theoretical investigations have provided evidence of the reactions of enterprises to the changes that the business environment demands by considering logistics flexibility as an essential variable (Box et al., 1993; Zahra \& Pearce, 1994; Wiklund, 1999; Miles et al., 2000; Verdú-Jover et al., 2006). This is why there is in the literature a substantial theoretical section regarding the effects of logistics flexibility in the results of business, which is analyzed with different names such as strategic flexibility (Woo et al., 1991; Stoica \& Schindehutte, 1999; Miles et al., 2000; Schindehutte \& Morris, 2001); structural flexibility (Randolph et al., 1991; Ackroyd, 1995; Chaston, 1997); operational flexibility (Chappell et al., 1993) or environmental flexibility (Verdú-Jover et al., 2006).

Likewise, the literature has considered logistics flexibility as a variable that allows a measurement of time in which organizations have changed, modified or adapted different components or processes such as products or services offered to their clients, their profile, advantages and space requirements in an effort to increase 
significantly the satisfaction of clients and consumers (Wright \& Snell, 1998). However, the relation between the level of logistics flexibility that enterprises have currently and the one needed, by the constant change in the market environment had not been analyzed or discussed in the literature as an explanatory variable of the results of enterprises, except in the investigations of Sánchez (1995), Rowe and Wright (1997) as well as Wright and Snell (1998).

At the beginning of this century, this problem has been analyzed and discussed in the literature more exhaustively where logistics flexibility has now been considered as a basic strategy to satisfy the specific needs of clients (Evers et al., 2000; Gunasekaran et al., 2001; Lummus et al., 2003; Closs et al., 2005; Martinez \& Perez, 2005; Zhang et al., 2006; Esper et al., 2007). Consequently, most enterprises are trying to give every time high value to their clients to achieve a higher level of satisfaction for them, since this will enable them to build a positive reputation and obtain a higher level of loyalty of their customers (Innis \& LaLonde, 1994; Daugherty et al., 1998; Stank et al., 2003; Zhang et al., 2005). Henceforth, it is necessary to establish the following hypothesis:

H1: A high level of logistics flexibility produces a high level of satisfaction from customers of enterprises from the furniture sector of Spain.

\subsection{Sampling Procedures}

An empirical research in the firms from the furniture sector in Spain in order to answer the hypothesis established by obtaining a business directory of 500 enterprises where 20 or more people work. Furthermore, the questionnaire was designed to be answered by the people in charge of the area of logistics of enterprises of the furniture sector within the 16 Autonomous Communities of Spain, which was sent by regular mail to each of the 500 enterprises selected. 322 validated questionnaires were returned with an error margin of $4.8 \%$ obtaining a reply range of 53\%. Similarly, the logistics flexibility was measured through four variables: flexibility of physical supply, flexibility of purchasing, flexibility of physical allocation and flexibility of the management of the demand, which are defined by one-dimensional scales just like the measurement scale of satisfaction of customers.

\subsection{Measures and Covariates}

The flexibility of physical supply was measured through a six-item scale which was adapted from Langley and Holcomb (1992); Day (1994); Carter and Narasimhan (1994); Bowersox and Closs (1996); as well as Zhang et al. (2005). The flexibility of purchasing was measured through a six-item scale which was adapted from Porter (1985), Ernst and Whinney (1987), Narasimhan and Carter (1998), Van Hoek (2001) as well as Zhang et al. (2005). The flexibility of physical allocation was measured through a six-item scale which was adapted from Langley and Holcomb (1992), Lambert and Stock (1993), Day (1994), Cooper et al. (1997), Van Hoek et al. (1998) as well as Zhang et al. (2005).

The flexibility of the management of the demand was measured through a five-item scale which was adapted from Langley and Holcomb (1992), Day (1994), Lengnick-Hall (1996), Lee (2001) as well as Zhang et al. (2005). Finally, the customer's satisfaction was measured through a six-item scale which was adapted from Tracey et al. (1999), Koufteros et al. (2002), Stank et al. (2003) as well as Zhang et al. (2005). The items of the five scales are built based on a Likert-type scale of five points $(1=$ completely disagree and $5=$ completely agree, as their limits).

Correspondingly, in order to evaluate reliability and validity of the five scales used in this research a second order Factorial Confirmatory Analysis (FCA), was carried out by using the method of maximum likelihood with the software EQS 6.1 (Bentler, 2005; Brown, 2006; Byrne, 2006). Also, the reliability of the scales was evaluated by means of Cronbach's alpha and the Composite Reliability Index (CRI) (Bagozzi \& Yi, 1988). The results obtained were higher to the recommended level of 0.7 which justifies the internal validity of the scales used (Nunally \& Bernstein, 1994; Hair et al., 1995). The suggestions of Chou, Bentler and Satorra (1991) as well as of $\mathrm{Hu}$, Bentler and Kano (1992) were taken into consideration regarding the correction of the statistics of the theoretical model, when it is considered that the normality of data is present by using also the robust statistics in order to provide a better statistical adjustment of data (Satorra \& Bentler, 1988).

The second order FCA results are shown in Table 1 and they indicate that the theoretical model has a good statistical adjustment of data $\left(S-B X^{2}=565.037 ; d f=366 ; p=0.000 ; N F I=0.986 ; N N F I=0.994 ; C F I=0.995\right.$; $R M S E A=0.041$ ). As evidence of convergent validity, the FCA results of second order indicate that the totality of the items of the factors related are significant $(\mathrm{p}<0.01)$, and the size of all the standardized factorial loads are above 0.60 (Bagozzi \& Yi, 1988). Moreover, the Extracted Variance Index (EVI) was calculated for each pair of constructs to obtain an EVI higher to the recommended value of 0.5 (Fornell \& Larcker, 1981). 
Table 1. Internal consistency and convergent validity of the theoretical model

\begin{tabular}{|c|c|c|c|c|c|c|}
\hline Variable & Indicator & $\begin{array}{c}\text { Loading } \\
\text { Factor }\end{array}$ & $\begin{array}{l}\begin{array}{l}\text { Robust } \\
\text { t-Value }\end{array} \\
\end{array}$ & $\begin{array}{c}\begin{array}{c}\text { Cronbach's } \\
\text { Alpha }\end{array} \\
\end{array}$ & CRI & EVI \\
\hline \multirow{6}{*}{$\begin{array}{c}\text { Flexibility of the Physical } \\
\text { Supply } \\
\text { (F1) }\end{array}$} & PS1 & $0.731 * * *$ & $1.000^{\mathrm{a}}$ & \multirow{6}{*}{0.841} & \multirow{6}{*}{0.862} & \multirow{6}{*}{0.509} \\
\hline & PS2 & $0.721 * * *$ & 16.722 & & & \\
\hline & PS3 & $0.696^{* * *}$ & 15.047 & & & \\
\hline & PS4 & $0.692 * * *$ & 16.158 & & & \\
\hline & PS5 & $0.716^{* * *}$ & 17.447 & & & \\
\hline & PS6 & $0.728 * * *$ & 17.598 & & & \\
\hline \multirow{6}{*}{$\begin{array}{l}\text { Flexibility of Purchasing } \\
\text { (F2) }\end{array}$} & PF1 & $0.693 * * *$ & $1.000^{\mathrm{a}}$ & \multirow{6}{*}{0.856} & \multirow{6}{*}{0.858} & \multirow{6}{*}{0.501} \\
\hline & PF2 & $0.741 * * *$ & 23.771 & & & \\
\hline & PF3 & $0.699 * * *$ & 17.818 & & & \\
\hline & PF4 & $0.696^{* * *}$ & 19.443 & & & \\
\hline & PF5 & $0.686^{* * *}$ & 17.923 & & & \\
\hline & PF6 & $0.734 * * *$ & 22.776 & & & \\
\hline \multirow{6}{*}{$\begin{array}{c}\text { Flexibility of the Physical } \\
\text { Distribution } \\
\text { (F3) }\end{array}$} & PD1 & $0.743 * * *$ & $1.000^{\mathrm{a}}$ & \multirow{6}{*}{0.851} & \multirow{6}{*}{0.863} & \multirow{6}{*}{0.513} \\
\hline & PD2 & $0.668 * * *$ & 21.718 & & & \\
\hline & PD3 & $0.662 * * *$ & 18.165 & & & \\
\hline & PD4 & $0.689 * * *$ & 22.131 & & & \\
\hline & PD5 & $0.752 * * *$ & 20.728 & & & \\
\hline & PD6 & $0.779 * * *$ & 26.157 & & & \\
\hline \multirow{5}{*}{$\begin{array}{l}\text { Flexibility of the Demand } \\
\text { Management } \\
\text { (F4) }\end{array}$} & PM1 & $0.761 * * *$ & $1.000^{\mathrm{a}}$ & \multirow{5}{*}{0.843} & \multirow{5}{*}{0.845} & \multirow{5}{*}{0.522} \\
\hline & PM2 & $0.755 * * *$ & 27.066 & & & \\
\hline & PM3 & $0.694 * * *$ & 20.447 & & & \\
\hline & PM4 & $692 * * *$ & 22.718 & & & \\
\hline & PM5 & $0.711 * * *$ & 24.136 & & & \\
\hline \multirow{4}{*}{ Logistics Flexibility } & F1 & $0.861 * * *$ & 14.109 & \multirow{4}{*}{0.953} & \multirow{4}{*}{0.959} & \multirow{4}{*}{0.855} \\
\hline & F2 & $0.926 * * *$ & 14.314 & & & \\
\hline & F3 & $0.928 * * *$ & 14.349 & & & \\
\hline & F4 & $0.981 * * *$ & 14.381 & & & \\
\hline \multirow{6}{*}{ Customer's Satisfaction } & CS1 & $0.767 * * *$ & $1.000^{\mathrm{a}}$ & \multirow{6}{*}{0.888} & \multirow{6}{*}{0.891} & \multirow{6}{*}{0.571} \\
\hline & $\mathrm{CS} 2$ & $0.791 * * *$ & 20.337 & & & \\
\hline & $\mathrm{CS} 3$ & $0.734 * * *$ & 22.576 & & & \\
\hline & CS4 & $0.739 * * *$ & 24.624 & & & \\
\hline & CS5 & $0.756^{* * *}$ & 23.775 & & & \\
\hline & CS6 & $0.744 * * *$ & 23.078 & & & \\
\hline \multicolumn{7}{|c|}{$S-B X^{2}(\mathrm{df}=366)=565.038 ; \mathrm{p}<0.000 ; \mathrm{NFI}=0.986 ; \mathrm{NNFI}=0.994 ; \mathrm{CFI}=0.995 ;$ RMSEA $=0.041$} \\
\hline
\end{tabular}

Regarding the evidence of the discriminant validity, the measurement is provided in two ways that can be seen more clearly in Table 2. Firstly, with an interval of $95 \%$ of reliability, none of the individual latent elements of the matrix of correlation has a value of 1.0 (Anderson \& Gerbing, 1988). Secondly, the extracted variance between each pair of constructs is lower than their corresponding EVI (Fornell \& Larcker, 1981). Based on these criteria, it is possible to conclude that the different measurements used in this research provide enough evidence of reliability as well as convergent and discriminant validity.

Table 2. Discriminant validity of the theoretical model

\begin{tabular}{|c|c|c|}
\hline Variables & Logistics Flexibility & Cus tomer's Satis faction \\
\hline Logistics Flexibility & 0.855 & 0.246 \\
\hline Cus tomer's Satis faction & $0.208 \quad-\quad 0.784$ & 0.571 \\
\hline
\end{tabular}

The diagonal represents the Extracted Variance Index (EVI), whereas above the diagonal the variance is presented (squared correlation). Below diagonal, the estimated correlation of factors is presented with $95 \%$ confidence interval.

\section{Results}

The theoretical model was analyzed in order to prove the hypothesis established in this empirical research by using the structural equations model (SEM) of second order with the software EQS 6.1 (Bentler, 2005; Brown, 2006; Byrne, 2006), with the same variables to confirm the structure of the theoretical model and obtain the results that allow contrasting the hypothesis stated at the beginning of this paper. Similarly, the nomological validity of the theoretical model was analyzed through the Chi-square test. It was mostly based on the comparison of the results obtained from the original model and the measurement model; that provided 
non-significant results statistically between the Chi-square of both models which provide an explanation of the relations observed between the constructs of the latent variable of the two models (Anderson \& Gerbing, 1988; Hatcher, 1994). The results obtained by means of the SEM can be seen in a more detailed way in Table 3.

Table 3. Results of the structural equation model of the theoretical model

\begin{tabular}{|c|c|c|c|}
\hline Hypothesis & Structural relation & \multirow{2}{*}{$\begin{array}{c}\begin{array}{c}\text { Standardized } \\
\text { coefficient }\end{array} \\
0.635^{* * *}\end{array}$} & \multirow{2}{*}{$\begin{array}{r}\begin{array}{r}\text { Robust } \\
\text { t-Value }\end{array} \\
9.038\end{array}$} \\
\hline $\begin{array}{l}\text { H1: Higher level of logistics } \\
\text { flexibility, higher level of } \\
\text { customer's satisfaction. }\end{array}$ & Logistics Fle. $\rightarrow$ Customer's Sat. & & \\
\hline \multicolumn{4}{|c|}{$S-B X^{2}(\mathrm{df}=366)=581.605 ; \mathrm{p}<0.000 ; \mathrm{NFI}=0.985 ; \mathrm{NNFI}=0.994 ; \mathrm{CFI}=0.994 ;$ RMSEA $=0.043$} \\
\hline
\end{tabular}

Regarding the first hypothesis $\mathbf{H 1}$ the results obtained $(\beta=0.635, \mathrm{p}<0.01)$ indicate that logistics flexibility has a significant positive impact in customer satisfaction, which verifies the hypothesis established at the beginning of this empirical research and it provides empirical evidence of a positive relation between both constructs. At this point, it is possible to conclude that logistics flexibility is an essential strategy to attain a higher level of customer satisfaction of enterprises from the furniture industry. Likewise, this result increases the analysis and discussion of the advantage of logistics flexibility as a business strategy that must be implemented in the daily activities of firms which will allow organization to obtain a higher level of satisfaction from their clients and consumers.

\section{Discussion}

According to the results obtained in this empirical research, it is possible to conclude in two fundamental aspects. Firstly, it is possible to measure logistics flexibility through four essential variables: flexibility of physical supply, flexibility of purchasing, flexibility of physical allocation and flexibility of the management of the demand. These four variables represent the fundamental activities that must take place in the logistics system that enterprises adopt and implement, especially the ones that belong to the furniture industry. Accordingly, the flexibility has to be implemented no only on these four activities but also in all the actions that imply the need of logistics and supply chains of enterprises as this will allow them to adapt to the requirements of clients and the market.

Secondly, it is likely to conclude that logistics flexibility has a positive and significant influence at the level of customer satisfaction. By making logistics activities more flexible, enterprises take the orders requested by their clients as fast as possible to the place selected, in the quantities requested and at the lowest possible cost. Therefore, clients and consumers feel more satisfied when enterprises customize not only the products demanded by them but also the logistics services used by applying the strategies such as delivering on time to achieve a higher level of loyalty from clients as this will allow enterprises of the furniture industry to have happy and satisfied customers which will turn into an important increase in the sales of their products.

To sum up, it is possible to conclude at a general level that this empirical research provides theoretical and empirical evidence of the existing relation between logistics flexibility and customer satisfaction which may take enterprises of the furniture industry to achieve higher levels of customer satisfaction by using flexible systems in their logistics activities and supply chain. Consequently, this research represents an initial investigation about the essence of logistics flexibility in a comprehension and understanding of the importance that this concept has in organizations because the construction of the existing relation between both constructs of logistics flexibility in a wide number of enterprises from the furniture industry and the level of customer satisfaction, allows to verify their positive and existing relation.

Additionally, these results also have important implications both for managers of enterprises from the industry of furniture and the organizations themselves since enterprises can get a higher level of customer satisfaction if they become more flexible in their activities and logistics systems which will turn into a fast restock of materials and an adequate delivery of the products requested. Thus, logistics flexibility can help managers to differentiate logistics activities that are critical for their clients from those activities that support and are essential to improve the processes of orders reception, compression of orders, transportation of products to established places, distribution to establishments or stores where the commercialization of products and the compliance of orders take place in general terms since this will allow enterprises to improve significantly the level of customer satisfaction.

This dichotomy of logistics flexibility allows managers to have a more general point of view about the importance of flexibility in the organization because it is precisely through the point of view of executives of 
enterprises that they will be able focus more in increasing their knowledge and skills to improve significantly the flexibility of activities and logistics systems in such a way that they can lead towards the improvement of the level customer satisfaction. Henceforth, in order to increase the level of customer satisfaction of enterprises from the furniture industry, the activities and logistics systems will have to be organized in such a way that they can react effectively and efficiently to the requirements and needs of clients by delivering the requested products as soon as possible, with the lowest and most competitive costs available in the market.

In the past, logistics systems, forecasting future sales, had already assigned the position of the deliveries of inventories in the distribution channels as soon as possible in order to have available products when customers needed them. The improvement of information technologies, such as internet, provides information in real time which allows logistics flexibility information to specify orders (Ghourly, 1996). Furthermore, logistics flexibility allows enterprises to customize the products and services offered without increasing the levels of stock. With logistics flexibility, organizations can offer new services such as the addition of future products or provide specific packaging, labels or configuration of products that can be aligned effortlessly to the individual needs of clients.

In this regard, the exchange of information created by the flexibility of logistics systems and activities allows a more effective coordination between manufacturing companies and their suppliers by delivering the necessary raw materials for the production process in due time and proper course to comply with the requested orders made by customers. Under those circumstances, the information produced in logistics processes becomes a vital element for an adequate management of inventories and, in this way, in an essential complement of materials flow (Closs et al., 1997). Consequently, managers of enterprises will have a better position to make better decisions by having factual and timely information produced by means of the flexibility of logistics systems which can create better result than those enterprises that make decisions by dividing the two functions (Lee \& Whang, 2000).

Additionally, this empirical research has different limitations that are important to specify at this moment. The first one of them is the size of the sample since the only enterprises considered from the furniture industry had twenty or more employees at the moment of implementing the questionnaire. Further investigations will need to consider the enterprises that have less than 20 employees. A second limitation is the one related to the information obtained since only a part of the information of logistics flexibility and customer satisfaction. An important percentage of the enterprises considered that the information requested was confidential so the information provided may not necessarily reflect the real situation of enterprises from the furniture industry.

A third limitation is the scale used for the measurement of both logistics flexibility and customer satisfaction because only four types of flexibility were used with 23 items to measure logistics flexibility and five items to measure customer satisfaction. Future investigations will need to use other scales to verify the results obtained. A final limitation is that the questionnaire was applied only to managers the people in charge of the area of logistics in enterprises from the furniture industry. This created the assumption that they had a lot of knowledge about the variables analyzed so further investigations will need to apply the same questionnaire to a different sample of managers as well as enterprises from other sectors and countries to verify the results obtained.

\section{References}

Ackroyd, S. (1995). On the structure and dynamics of some small, UK-based information technology firms. Journal of Management Studies, 32(2), 141-161.https://doi.org/10.1111/j.1467-6486.1995.tb00338.x

Anderson, J., \& Gerbing, D. (1988). Structural equation modeling in practice: a review and recommended two-step approach. Psychological Bulletin, 13, 411-423. https://doi.org/10.1037/0033-2909.103.3.411

Ansoff, H. L., \& Brandenburg, R. G. (1971). A language for organizations design: Part 1. Management Science, 17(12), 705-716. https://doi.org/10.1287/mnsc.17.12.B705

Aprile, D., Garavelli, C., \& Giannoccaro, I. (2005). Operations planning and flexibility in a supply chain. Production Planning \& Control, 16(1), 21-31. https://doi.org/10.1080/09537280412331313348

Ashenbaum, B., Maltz, A., \& Rabinovich, E. (2005). Studies of trends in third-party logistics usage: What can we conclude? Transportation Journal, 44(3), 39-50.

Bagozzi, R. P., \& Yi, Y. (1988). On the evaluation of structural equation models. Journal of the Academy of Marketing Science, 16(1), 74-94. https://doi.org/10.1007/BF02723327

Baumol, W., \& Vinod, H. (1970). An inventory theoretic model of freight transport demand. Management Science, 16(7), 413-421. https://doi.org/10.1287/mnsc.16.7.413 
Bentler, P. M. (2005). EQS 6 structural equations program manual. Encino, CA: Multivariate Software.

Bower, J. L., \& Hout, T. M. (1988). Fast-cycle capability for competitive power. Harvard Business Review, 66(6), $110-118$.

Bowersox, D. J., \& Closs, D. J. (1996). Logistical management: the integrated supply chain process. $4^{\text {th }}$ Edition. New York, NY: McGraw-Hill.

Bowersox, D. L., Daugherty, P., Dröge, C., Rogers, D., \& Wardlow, D. (1989). Leading Edge Logistics: Competitive Positioning for the 1990s. Oak Brook, IL: Council of Logistics management.

Box, T. M., White, M. A., \& Starr, S. H. (1993). A contingency model of new manufacturing firm performance. Entrepreneurship Theory \& Practice, 18(2), 31-46.

Brown, T. (2006). Confirmatory factor analysis for applied research. New York, NY: The Guilford Press.

Buffa, F., \& Reynolds, J. (1977). The inventory-transport model with sensitive analysis by indifference curves. Transportation Journal, 17(1), 83-90.

Byrne, B. (2006). Structural equation modeling with EQS, basic concepts, applications, and programming. 2th Edition, London: LEA Publishers.

Cannon, J. P., \& Homburg, C. (2001). Buyer-supplier relationships and customer firm costs. Journal of Marketing, 65(1), 29-43. https://doi.org/10.1509/jmkg.65.1.29.18136

Carlson, B. (1989). Flexibility and the theory of the firm. International Journal of Industrial Organization, 7(1), 179-203. https://doi.org/10.1016/0167-7187(89)90018-0

Carter, J. R., \& Narasimhan, R. (1994). The role of purchasing and materials management in total quality management and customer satisfaction. International Journal of Purchasing and Materials Management, 30(3), 3-13. https://doi.org/10.1111/j.1745-493x.1994.tb00190.x

Chang, S. C., Lin, R. J., Chen, J. H., \& Huang, L. H. (2005). Manufacturing flexibility and manufacturing proactiveness: Empirical evidence from the motherboard industry. Industrial Management \& Data System, 105(8), 1115-1132. https://doi.org/10.1108/02635570510624482

Chappell, W. F., Mayer, W. J., \& Shughart, W. F. (1993). Firm heterogeneity and production flexibility: Evidence from price-cost margins of large and small firms. Bulletin of Economic Research, 45(3), 229-244. https://doi.org/10.1111/j.1467-8586.1993.tb00568.x

Chase, R. B., Aquilano, N. J., \& Jacobs, R. (2000). Operations management for competitive advantage, Boston, MA: Irwin/McGraw-Hill.

Chaston, I. (1997). Small firm performance: Assessing the interaction between entrepreneurial style and organizational structure. European Journal of Marketing, 31(11-12), 814-834. https://doi.org/10.1108/03090569710190550

Chou, C. P., Bentler, P. M., \& Satorra, A. (1991). Scaled test statistics and robust standard errors for nonnormal data in covariance structure analysis. British Journal of Mathematical and Statistical Psychology, 44, 347-357. https://doi.org/10.1111/j.2044-8317.1991.tb00966.x

Closs, D. J., Goldsby, T., \& Clinton, S. (1997). Information technology influences on world class logistics capability. International Journal of Physical Distribution \& Logistics Management, 27(1), 4-17. https://doi.org/10.1108/09600039710162259

Closs, D. J., Swink, M., \& Nair, A. (2005). The role of information connectivity in making flexible logistics programs successful. International Journal of Physical Distribution \& Logistics Management, 35(4), 258-277. https://doi.org/10.1108/09600030510599922

Cooper, J. C., Lambert, D. M., \& Pagh, J. D. (1997). Supply chain management: More than a new name for logistics. The International Journal of Logistics Management, 8(1), 1-14. https://doi.org/10.1108/09574099710805556

Daugherty, P., \& Pittman, P. (1995). Utilization of time-based strategies: Creating distribution flexibility/responsiveness. International Journal of Operation \& Production Management, 15(2), 54-60. https://doi.org/10.1108/01443579510080418

Daugherty, P., Theodore, P., \& Ellinger, A. (1998). Leveraging logistics/distribution capabilities: The impact of logistics service on market share. Journal of Business Logistics, 19(2), 35-51. 
Day, G. S. (1994). The capabilities of market-driven organizations. Journal of Marketing, 58(4), 37-52. https://doi.org/10.2307/1251915

Deepen, J. M., Goldsby, T. J., Knemeyer, A. M., \& Wallenburg, C. M. (2008). Beyond expectations: An examination of logistics outsourcing goal achievement and goal exceedance. Journal of Business Logistics, 29(2), 75-105. https://doi.org/10.1002/j.2158-1592.2008.tb00088.x

Ernst, E., \& Whinney, W. (1987). Corporate profitability and logistics: Innovative guidelines for executives. Oak Brook, IL: Council of Logistics Management.

Esper, T. I., Fugate, B. S., \& Sramek, B. D. (2007). Logistics learning capability: sustaining the competitive advantage gained through logistics leverage. Journal of Business Logistics, 28(2), 57-81. https://doi.org/10.1002/j.2158-1592.2007.tb00058.x

Evers, J., Loeve, L., \& Lindeijer, D. (2000). New logistics control: concepts, architectures and logistics programming. Paper presented at $3^{\text {rd }}$ International Meeting for Research in Logistics, Trois-Rivieres.

Fawcett, S. E., Calantone, R. J., \& Smith, S. R. (1996). An investigation of the impact of flexibility on global reach and firm performance. Journal of Business Logistics, 17(2), 167-196.

Fisher, M. L. (1997). What is the right supply chain for your product? Harvard Business Review, March/April, 105-116.

Fornell, C., \& Larcker, D. (1981). Evaluating structural equation models with unobservable variables and measurement error. Journal of Marketing Research, 18(1), 39-50. https://doi.org/10.2307/3151312

Gebauer, J., \& Schober, F. (2006). Information system flexibility and the cost efficiency of business processes. Journal of the Association for Information Systems, 7(3), 122-147.

Ghourly, C. (1996). Retail logistics in cyberspace. Distribution, 95, 29-31.

Gilmore, J. H., \& Pine, J. B. (1997). The four faces of mass customization. Harvard Business Review, 75(1), 91-101.

Grawe, S. J., Daugherty, P. J., \& Roath, A. S. (2011). Knowledge synthesis and innovative logistics processes: Enhancing operational flexibility and performance. Journal of Business Logistics, 32(1), 69-80. https://doi.org/10.1111/j.2158-1592.2011.01006.x

Gunasekaran, A., Patel, C., \& Tirtiroglu, E. (2001). Performance measures and metrics in a supply chain environment. International Journal of Operations and Production Management, 21(1/2), 71-87. https://doi.org/10.1108/01443570110358468

Hair, J. F., Anderson, R. E., Tatham, R. L., \& Black, W. C. (1995). Multivariate data analysis with readings. New York, NY: Prentice-Hall.

Hartmann, E., \& De Grahl, A. (2011). The flexibility of logistics service providers and its impact on customer loyalty: An empirical study. Journal of Supply Chain Management, 47(3), 63-85. https://doi.org/10.1111/j.1745-493X.2011.03228.x

Hatcher, L. (1994). A step by step approach to using the SAS system for factor analysis and structural equation modeling. Cary, NC: SAS Institute Inc.

Hill, T. (1985). Manufacturing strategies. Basingstoke: Macmillan.

Homburg, C., Giering, A., \& Menon, A. (2003). Relationship characteristics as moderators of the satisfaction-loyalty link: Findings in a business-to-business context. Journal of Business-to-Business Marketing, 10(3),35-62. https://doi.org/10.1300/J033v10n03_02

Hu, L. T., Bentler, P. M., \& Kano, Y. (1992). Can test statistics in covariance structure analysis be trusted? Psychological Bulletin, 112(2), 351-362. https://doi.org/10.1037/0033-2909.112.2.351

Innis, D. E., \& LaLonde, B. J. (1994). Customer service: the key to customer satisfaction, customer loyalty and market share. Journal of Business Logistics, 15(1), 1-28.

Jayaraman, V. (1998). Transportation, facility location and inventory issues in distribution network design: an investigation. International Journal of Operations \& Production Management, 18(5), 471-494. https://doi.org/10.1108/01443579810206299

Jenkins, G. P., \& Wright, D. S. (1998). Managing inflexible supply chains. The International Journal of Logistics Management, 9(2), 83-90. https://doi.org/10.1108/09574099810805852 
Johnson, J. L., Lee, R. P. W., \& Grohmann, B. (2003). Market-focused strategic flexibility: Conceptual advances and an integrated model. Journal of the Academy of Marketing Science, 31(1), 74-89. https://doi.org/10.1177/0092070302238603

Julie, H. (2005). Influence of flexibilities on manufacturing cells for faster delivery using simulation. Journal of Manufacturing Technology Management, 16(8), 825-841. https://doi.org/10.1108/17410380510627843

Kayis, B., \& Kara, S. (2005). The supplier and customer contribution to manufacturing flexibility: Australian manufacturing industry's perspective. Journal of Manufacturing Technology Management, 16(7), 733-752. https://doi.org/10.1108/17410380510626169

Knemeyer, A. M., \& Murphy, P. R. (2004). Evaluating the performance of third-party logistics arrangements: A relationship marketing performance. Journal of Supply Chain Management, 40(1), 35-51. https://doi.org/10.1111/j.1745-493X.2004.tb00254.x

Knemeyer, A. M., \& Murphy, P. R. (2005a). Is the glass half full or half empty? An examination of user and provider perspectives towards third-party logistics relationships. International Journal of Physical Distribution \& Logistics Management, 35(10), 708-727. https://doi.org/10.1108/09600030510634571

Knemeyer, A. M., \& Murphy, P. R. (2005b). Exploring the potential impact of relationship characteristics and customer attributes on the outcomes of third-party logistics arrangements. Transportation Journal, 44(1), 5-19.

Kogut, B. (1985). Designing global strategies: Profiting from operational flexibility. Sloan Management Review, 27(1), 27-38.

Koufteros, X. A., Vonderembse, M., \& Doll, W. (2002). Examining the competitive capabilities of manufacturing firms. Structural Equation Modeling, 9(2), 256-282. https://doi.org/10.1207/S15328007SEM0902_6

Lambert, D. M., \& Stock, J. R. (1993). Strategic logistics management. 3er Edition. Boston, MA: Irwin.

Langley, C. J., \& Holcomb, M. C. (1992). Creating logistics customer value. Journal of Business Logistics, 13(2), $1-27$.

Langley, C. J., Albright, D., Morton, J., Wereldsma, D., Alf, M., Swaminathan, S., ... Peters, K. (2009). The state of logistics outsourcing: 2009 third-party logistics - results and findings of the $14^{\text {th }}$ annual study. $14^{\text {th }}$ Annual Study, Atlanta.

Lee, H. L. (2001). Ultimate enterprise value creation using demand-based management. Stanford Global Supply Chain Management Forum Working Paper Series, SGSCMF-W1-2001.

Lee, H. L., \& Wang, S. (2000). Information sharing in a supply chain. International Journal of Technology Management, 20(3/4), 373-387. https://doi.org/10.1504/IJTM.2000.002867

Lengnick-Hall, C. (1996). Customer contribution to quality: A different view of the customer-oriented firm. Academy of Management Review, 21, 791-824.

Lieb, R., \& Butner, K. (2007). The North American third-party logistics industry in 2006: The provider CEO perspective. Transportation Journal, 46(3), 40-52.

Ling-Yee, L., \& Ogunmokun, G. O. (2001). The influence of interfirm relational capabilities on export advantage and performance: An empirical analysis. International Business Review, 10(4), 399-420. https://doi.org/10.1016/S0969-5931(01)00023-3

Lummus, R., Duclos, L., \& Vokurka, R. (2003). Supply chain flexibility: building a new model. Global Journal of Flexible Systems Management, 4(4), 1-13.

Martinez, A., \& Perez, M. (2005). Supply chain flexibility and firm performance: A conceptual model an empirical study in the automotive industry. International Journal of Operations \& Production Management, 25(7), 681-700. https://doi.org/10.1108/01443570510605090

Miles, M. P., Covin, J. G., \& Heeley, M. B. (2000). The relationship between environmental dynamism and small firm structure, strategy and performance. Journal of Marketing Theory \& Practice, 8(2), 63-75. https://doi.org/10.1080/10696679.2000.11501869

Naim, M. M., Potter, A. T., Mason, R. J., \& Bateman, N. (2006). The role of transport flexibility in logistics provision. The International Journal of Logistics Management, 17(3), 297-311. https://doi.org/10.1108/09574090610717491

Narasimhan, R., \& Carter, J. (1998). Linking business unit and material sourcing strategies. Journal of Business 
Logistics, 19(2), 155-171.

Noordewier, T.G., John, G., \& Nevin, J.R. (1990). Performance outcomes of purchasing arrangements in industrial buyer-vendor relationships. Journal of Marketing , 54(4), 80-93. https://doi.org/10.2307/1251761

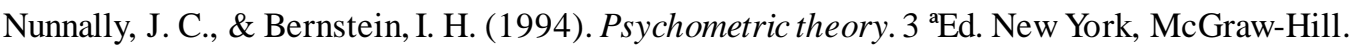

Oke, A. (2005). A framework for analyzing manufacturing flexibility. International Journal of Operations \& Production Management, 25(10), 973-996. https://doi.org/10.1108/01443570510619482

Pine, J. B. (1997). Mass customization: The new frontier in business competition. Cambridge, MA: Business School Press.

Porter, M. E. (1985). Competitive strategy: Creating and sustaining superior performance. New York, NY: Free Press.

Randolph, W. A., Sapienza, H. J., \& Watson, M. A. (1991). Technology-structure fit and performance in small business: An examination of the moderating effects of organizational states. Entrepreneurship Theory \& Practice, 16(1), 27-41.

Rowe, W. G., \& Wright, P. M. (1997). Related and unrelated diversification and their effect on human-resource management controls. Strategic Management Journal, $18(4), \quad 329-338$. https://doi.org/10.1002/(SICI)1097-0266(199704)18:4<329::AID-SMJ879>3.0.CO;2-W

Sanchez, R. (1995). Strategic flexibility in product competition. Strategic Management Journal, 16(1), 63-76. https://doi.org/10.1002/smj.4250160921

Satorra, A., \& Bentler, P. M. (1988). Scaling corrections for chi square statistics in covariance structure analysis. American Statistics Association 1988 Proceedings of the Business and Economic Sections, 208-313.

Schindehuette, M., \& Morris, M. H. (2001). Understanding strategic adaptation in small firm. International Journal of Entrepreneurial Behaviour \& Research, 7(3), 84-107. https://doi.org/10.1108/EUM0000000005532

Shang, K., \& Marlow, P. B. (2005). Logistics capability and performance in Taiwan's mayor manufacturing firms. Transportation Research Part E, 41(3), 217-234. https://doi.org/10.1016/j.tre.2004.03.002

Slack, N. (1990). The manufacturing advantage. London: Mercury.

Stank, G., Evans, P., \& Schulman, L. E. (1992). Competing on capabilities: the new rules of corporate strategy. Harvard Business Review, 70(2), 57-69.

Stank, T. P., Goldsby, T. J., Vickery, S., \& Savitskie, K. (2003). Logistics service performance: Estimating its influence on market share. Journal of Business Logistics, 21(1), 27-55. https://doi.org/10.1002/j.2158-1592.2003.tb00031.x

Stevenson, M., \& Spring, M. (2007). Flexibility from a supply chain perspective: Definition and review. International Journal of Operations \& Production Management, 27(7), 685-713. https://doi.org/10.1108/01443570710756956

Stoica, M., \& Schindehutte, M. (1999). Understanding adaptation in small firm: Links to culture and performance. Journal of Developmental Entrepreneurship, 4(1), 1-15.

Tang, C., \& Sia, S. (2006). Managing flexibility in outsourcing. Journal of the Association for Information Systems, 7(4), 179-206.

Tracey, M. A., Vonderembse, M. A., \& Lim, J. S. (1999). Manufacturing technology and strategy formulation: Keys to enhancing competitiveness and improving performance. Journal of Operations Management, 17(4), 411-428. https://doi.org/10.1016/S0272-6963(98)00045-X

Upton, D. (1995b). Flexibility as process mobility: the management of plant capabilities for quick response manufacturing. Journal of Operations Management, 12(3/4), 205-224. https://doi.org/10.1016/0272-6963(95)00004-C

Upton, D. (1995c). Flexibility and factories. Harvard Business Review, 4, 74-84.

Upton, D. M. (1995a). What really makes factories flexible? Harvard Business Review, 73(4), 74-84.

Van Hoek, R. (2001). The discovery of postponement a literature review and directions for research. Journal of Operations Management, 19(2), 161-184. https://doi.org/10.1016/S0272-6963(00)00057-7

Van Hoek, R., Commandeur, H., \& Vos, B. (1998). Reconfiguring logistics systems through postponement 
strategies. Journal of Business Logistics, 19(1), 33-54.

Vannieuwenhuyse, B., Gelders, L., \& Pintelon, L. (2003). An online decision support system for transportation mode choice. Logistics Information Systems, 16(2), 125-133. https://doi.org/10.1108/09576050310467269

Verdú-Jover, A., Lloréns-Montes, F. J., \& Garcia-Campos, V. J. (2006). Environment-flexibility and performance: An analysis in large versus small firms. Journal of Small Business Management, 44(3), 334-349. https://doi.org/10.1111/j.1540-627X.2006.00175.x

Wallenburg, C. M. (2009). Innovation in logistics outsourcing relationships: Proactive improvements by logistics service providers as a driver of customer loyalty. Journal of Supply Chain Management, 45(2), 75-93. https://doi.org/10.1111/j.1745-493X.2009.03164.x

Wiklund, J. (1999). The sustainability of the entrepreneurial orientation-performance relationship. Entrepreneurship Theory \& Practice, 24(1), 37-47.

Woo, C. Y., Cooper, A. C., \& Nicholls-Nixon, C. (1991). Experimentation and performance in start-up firms. In Grave, W.D., Covin, J.C., Sexton, D.L., Slevin, D.P., Vesper, K.H. and Wetzel, W.E. (Eds.), Frontiers of Entrepreneurship Research. Wellesley, MA: Babson College, pp. 306-319.

Wright, P., \& Snell, S. A. (1998). Toward a unifying framework for exploring fit and flexibility in strategic human resource management. The Academy of Management Review, 23(4), 756-773.

Zahra, S. A., \& Pearce, J. A. (1994). Corporate entrepreneurship in smaller firms: The role of environment, strategy and organization. Entrepreneurship, Innovation and Change, 3(1), 31-44.

Zhang, Q., Vonderembse, M. A., \& Lim, J. S. (2005). Logistics flexibility and its impact on customer satisfaction. The International Journal of Logistics Management, 16(1), 71-95. https://doi.org/10.1108/09574090510617367

\section{Copyrights}

Copyright for this article is retained by the author(s), with first publication rights granted to the journal.

This is an open-access article distributed under the terms and conditions of the Creative Commons Attribution license (http://creativecommons.org/licenses/by/4.0/). 